\title{
Application of Molecular Breeding for Development of the Drought-Tolerant Genotypes in Wheat
}

\author{
Mohamed Najeb Barakat* and Abdullah Abdullaziz Al-Doss \\ Plant Genetic Manipulation and Genomic Breeding Group, \\ Center of Excellence in Biotechnology Research, \\ College of Food and Agricultural, \\ King Saud University, Riyadh \\ Saudi Arabia
}

\section{Introduction}

Drought is one of the most important environmental challenges growers have to face around the world. Drought is the cause for large grain losses every year, especially in developing countries, and the current trend in global climate change will likely lead to further losses. The worldwide water shortage and uneven distribution of rainfall makes the improvement of drought tolerance especially important (Lou and Zhang, 2001). Breeding for drought tolerance is a major objective in arid and semiarid regions of the world due to inadequate precipitation, shortage of irrigation water and high water demand for crop evapotranspiration in such climates. Little progress has been made in characterizing the genetic determinants of drought tolerance, because it is a complex phenomenon (Tripathy et $a l, 2000)$. Breeding for water stress tolerance by traditional methods is a time consuming and considered inefficient procedure. Improving the drought tolerance of a crop is difficult for a breeder because yield usually has a relatively low heritability even under ideal condition and an unpredictably variable water supply reduces heritability (Blum, 1988).

Drought tolerance is now considered by both breeders and molecular biologists to be a valid breeding target. In the past, breeding efforts to improve drought tolerance have been hindered by its quantitative genetic basis and our poor understanding of the physiological basis of yield in water-limited conditions (Passioura, 2002). Recently, Tuberosa and Saliva (2007) reported that genomics based approaches provide access to agronomically desirable alleles present at quantitative trait loci (QTLs) that affect such responses, thus enabling us to improve the drought tolerance and yield of crops under water limited conditions more effectively.

Compared to conventional approaches, genomics offers unprecedented opportunities for dissecting quantitative traits into their single genetic determinants (QTLs), thus paving the way to marker-assisted selection (MAS) (Ribaut et al,2002; Morgante and Salamini, 2003) and eventually, cloning of genes at target QTLs (Salivi and Tuberosa, 2005).Recently, Tuberosa

${ }^{*}$ Corresponding Author 
and Salivi (2007) demonstrated that how the information on QTLs governing the response to drought and candidate genes responsible for QTL effects can be used to elucidate the physiological basis of drought tolerance and to select genotypes with an improved yield under water-limited condition.

Molecular markers improve the efficiency of breeding by allowing manipulation of the genome through marker-assisted selection. Leaf senescence is the sequence of biochemical and physiological events comprising the final stage of leaf development from the mature fully extended state, until death. It is induced either by internal hormonal factors related to ageing, or, prematurely, by external environmental factors such as high temperature and drought (Chandler, 2001). In wheat (Triticum aestivum L.), flag leaf senescence (FLS) relates to the period of reallocating resources from the source to the sink during grain filling. Since flag leaf photosynthesis in wheat contributes about $30-50 \%$ of the assimilates for grain filling (Sylvester-Bradley et al., 1990), the onset and rate of senescence are important factors for determining yield potential (Evans, 1993). In order to identify molecular markers for flag leaf senescence, it is first necessary to construct a genetic map as a tool for discovering the genetic factors as quantitative trait loci (QTL). Though QTLs influencing senescence have been identified both in sorghum (Tuinstra et al., 1997; Crasta et al., 1999; Xu et al., 2000; Kebede et al., 2001; Harris et al, 2007) and maize (Beavis et al., 1994). Mapping quantitative trait loci for flag leaf senescence as a yield determinant in winter wheat under optimal and drought-stressed environments have been reported (Verma et al, 2004).

In the near future, molecular markers can provide simultaneous and sequential selection of agronomically important genes in wheat breeding programs allowing screening for several agronomically important traits at early stages and efficiently replace time consuming bioassays in early generation screens (Patnuk and Khurana, 2001). They also reported that application of biotechnology will thus contribute greatly to improving yield stability by generating plants with improved resistance to biotic and stresses rather than raising the overall yield. The coming years will undoubtedly witness an increasing application of genomics-assisted breeding for the genetic improvement of wheat. The goal of wheat breeding is to combine desirable genes from different lines into new varieties. However, it is often difficult to monitor for the presence of multiple desirable genes during the selection process. Genomics has revolutionized plant breeding by providing tools for highthroughput marker evaluations, which can be used in Marker-Assisted Selection (MAS) strategies for variety improvement.

The application of molecular markers to plant breeding can be divided into three main categories:(I) the characterization of germplasm, known as fingerprinting; (II) the genetic dissection of the target trait- actually the identification and characterization of genomic regions involved in the expression of the target trait; and (III) following the identification of the genomic regions of interest, crop improvement through marker-assisted selection (MAS). The first two applications have proved themselves by generating knowledge about the genetic diversity of germplasm, thereby allowing placement into heterotic groups and a better understanding of the genetic basis of agronomic traits of interest. For simply inherited traits - those that have high heritability and are regulated by only a few genes-the use of molecular markers to accelerate germplasm improvement has been well documented (e.g. Johnson and Mumm, 1996; Mohan et al., 1997; Young, 1999).Such work has proved successful in: (i) tracing favorable alleles in the genomic background of genotypes of 
interest; and (ii) identifying individual plants in large segregating populations that carry the favorable alleles. Moreover, with the recent development of PCR-based markers, for example, simple sequence repeats (SSRs) (Chinetal., 1996; Powelletal.,1996) and single nucleotide polymorphisms(SNPs) (Gilles et al., 1999), a substantial improvement in the capacity to efficiently screen large populations has been achieved, thereby increasing the efficiency of MAS experiments.

\section{Development of drought tolerance-associated DNA markers}

Twelve wheat genotypes were used in this study. These included the two recommended cultivars (Yecora Rojo and West Bread) as well as ten advanced lines (F8) selected from the wheat breeding program at the Plant Production Department, College of Food and Agriculture Sciences, King Saud University, Saudi Arabia. They evaluated phenotypically for drought tolerance and were planted under four irrigation treatments over two seasons to expose genotypes to different level of drought stress during filling period. The four irrigation treatments were formed by irrigation scheduled at cumulative pan evaporation (CPE) of T1:50, T2:100, T3:150 and T4:200 mm during the entire irrigation interval. The CPE was calculated as sum of daily recorded evaporation from USWB open pan. The pan was located at the Meteorological Station adjacent the experimental site. Two types of molecular markers, (RAPD) and (ISSR), were assayed to determine the genetic diversity of 12 wheat genotypes and to develop of drought tolerance-associated DNA markers.

The potential of using markers generated in the current study to develop drought tolerance - associated DNA markers is presented in Table 1. For the RAPD analysis presented here some wheat genotypes reported to be drought tolerant/sensitive (on the basis of field performance) were used. Figure 1 and Table 1 indicated that a DNA band at about $310 \mathrm{bp}$ that are present in Ksu103 as a drought tolerance, but not in Yecora Rojo as drought sensitive, when primer OPE20 is used .On the other hand, specific DNA bands at 1400bp and $1200 \mathrm{bp}$ are present in Yecora Rojo as drought sensitive, but not in the Ksu103 and Ksu105 as a drought tolerance, when primer OPE20 was used. Moreover, specific DNA bands generated from RAPD primers (Table 1) could be used to characterize between Ksu103 and Ksu105 (drought tolerance) and Yecora Rojo (drought sensitive). For the ISSR analysis, a polymorphic DNA fragments of 950bp and 740bp were identified in Ksu103 as well as Ksu105 and were absent in the Yecora Rojo, when primer ISSR-811was used (Fig.1; Table 1). These fragments appear to be linked to drought tolerance genes .On the other hand, specific DNA bands at $1200 \mathrm{bp}$ and 1040bp are present in Yecora Rojo as drought sensitive, but not in the Ksu103 and Ksu105 as a drought tolerance. In addition, specific DNA bands generated from ISSR primers (Table 1) could be used to characterize between Ksu103 as well as Ksu105 (drought tolerance) and Yecora Rojo (drought sensitive). The reproducibility of these variety specific markers was confirmed in RAPD and ISSR analyses for which DNA isolation, PCR amplification, and gel electrophoresis were carried out separately. Molecular marker technology has allowed the identification and genetic characterization of QTLs with significant effects on stress tolerance during different stages of plant development and facilitated determination of genetic relationships among tolerance to different stresses (Foolad 2005). Comparatively, however, limited research has been conducted to identify genetic markers associated with drought tolerance in different plant species. 


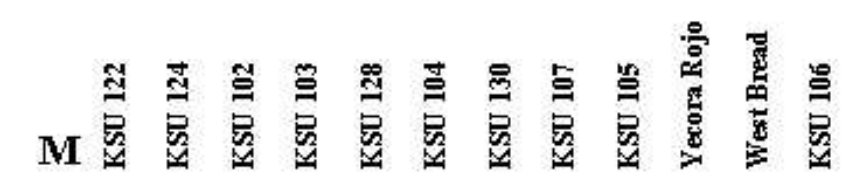
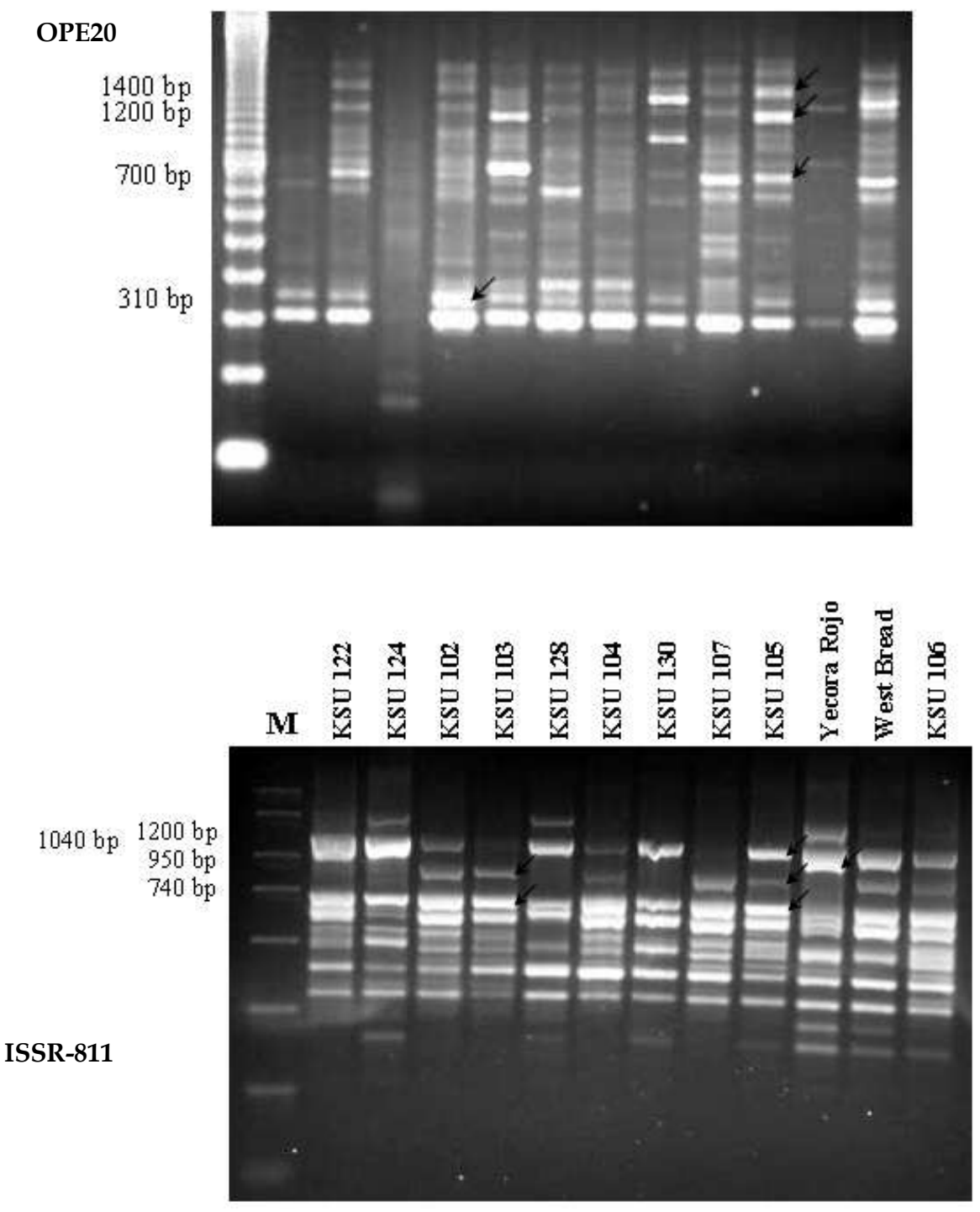

Fig. 1. Polymorphic DNA fragments linked to drought tolerance genes, generated by RAPD primer OPE20 (5`AACGGTGACC 3') and generated by ISSR primer ISSR-811 (5` G (AG) 7AC 3') M: Molecular weight, followed by wheat genotypes. 


\begin{tabular}{llllllllll}
\hline Primer & Marker & Ksu105 & $\begin{array}{l}\text { Yocora } \\
\text { Rojo }\end{array}$ & Ksu103 & Primer & Marker & Ksu105 & $\begin{array}{l}\text { Yocora } \\
\text { Rojo }\end{array}$ & Ksu103 \\
\hline Pr10 & 680 & + & - & + & ISSR-811 & 1200 & - & + & - \\
Pr16 & 750 & + & - & - & & 1040 & - & + & - \\
& 500 & + & - & + & & 950 & + & - & + \\
& 250 & + & - & + & & 740 & + & - & + \\
OPC04 & 300 & + & - & - & ISSR-816 & 500 & + & - & + \\
OPC15 & 630 & - & + & + & ISSR-817 & 540 & - & + & - \\
OPE20 & 1400 & - & + & - & & 520 & + & - & + \\
& 1200 & - & + & - & ISSR-11 & 280 & - & + & + \\
& 700 & + & + & - & ISSR-821 & 900 & - & + & - \\
& 310 & - & - & + & & 850 & + & - & - \\
OPE15 & 620 & - & - & + & & 320 & - & + & - \\
& 410 & + & - & + & & & & & \\
OPZ03 & 1400 & - & + & + & & & & &
\end{tabular}

Table 1. Specific DNA fragments generated from RAPD and ISSR analysis to develop drought tolerance-associated DNA markers between Yecora Rojo (drought-sensitive) and Ksu 105\& Ksu 103 (drought-tolerance).

\section{Drought QTL identification}

Genetic mapping with dense marker maps can be used to identify the number and genetic positions of Quantitative Trait Loci (QTL) associated with a specific phenotype under drought stress. In addition, this process can be used to estimate effects of the segregating QTL and their contributions to trait variation (individually and in combined QTL models), and obtain estimates of their stability across environments (QTL $\times$ E interactions) and across genetic back- grounds (QTL x QTL interactions).

The timing of flag leaf senescence is an important determinant of yield under stress and optimal environments. A segregating populations from the two crosses; the first cross between drought sensitive genotype (Variant-2 which was derived from Gemeza 1 cultivar; using somaclonal variation (Barakat et al., 2005)) and drought tolerant genotype (Cham-6) and the second cross between drought sensitive genotype (Variant-1 which was derived from Sakha 69 cultivar, using somaclonal variation tool (Barakat et al., 2005)) and 
drought tolerant genotype (Veery), were made to identify molecular markers linked to flag leaf senescence in wheat under water-stressed conditions. This trait was utilized as an indicator for drought tolerance genes and mapping QTL for flag leaf senescence in $F_{2}$ populations using bulked segregant analysis. Thirty-eight RAPD primers, twenty-five ISSR primers and fourty -six SSR primers were tested for polymorphism among parental genotypes and $F_{2}$ population.

Drought tolerance evaluation have been made to identify molecular markers linked to flag leaf senescence: One hundred $\mathrm{F}_{2}$ plants and their parents were planted in polyethylene bags (13 cm diameter, $15 \mathrm{~cm}$ height) under green house conditions in the winter season of 2008 to evaluate drought tolerance. All plants were grown at $20 / 15^{\circ} \mathrm{C}$ (day/night), with $50 / 70 \%$ relative humidity and16-h photoperiod. The bags were filled with sandy soil $(3.5 \mathrm{~kg})$ and were given the total amount of daily irrigation until reaching booting stage. Drought tests were carried using $50 \%$ of the amount of daily irrigation. Daily irrigation water requirements were calculated by CROPWAT software (Smith 1991) from agrometeorological data of the studied area and Kc of wheat as follows.

$$
\begin{gathered}
\text { ETo }=\frac{0.408 \Delta(R n-G)+\gamma \frac{37}{T h r+273} u 2\left(e^{\circ}(\mathrm{Thr})-\mathrm{e} a\right)}{\Delta+\gamma(1+0.34 \mathrm{u} 2)} \\
\text { ETc }=\text { Eto }^{*} \mathrm{Kc}
\end{gathered}
$$

Where, ETc $=$ Evapotranspiration for crop, $\mathrm{Kc}=$ Crop coefficient, ETo =Reference evapotranspiration $\left(\mathrm{mm} \mathrm{h}^{-1}\right), \mathrm{Rn}=$ net radiation at the grass surface, $\left(\mathrm{MJ} \mathrm{m}-2 \mathrm{~h}^{-1}\right), \mathrm{G}=$ soil heat flux density $\left(\mathrm{MJ} \mathrm{m}-2 \mathrm{~h}^{-1}\right)$, Thr = mean hourly air temperature $\left({ }^{\circ} \mathrm{C}\right), \Delta=$ Saturation slope vapor pressure curve at $\operatorname{Thr}\left(\mathrm{kPa}^{\circ} \mathrm{C}^{-1}\right), \gamma=$ psychrometric constant $\left(\mathrm{kPa}{ }^{\circ} \mathrm{C}^{-1}\right)$, eo $(\mathrm{Thr})=$ saturation vapor pressure at air temperature $\mathrm{Thr}$, ea $=$ average hourly actual vapor pressure, $\mathrm{u} 2=$ average hourly actual wind speed $\left(\mathrm{ms}^{-1}\right)$.

Calculated ETc, (crop evapotranspiration), which is equal $100 \%$ of daily water consumption use for the wheat was used to calculate irrigation requirements with the following equation:

$$
\text { Daily irrigation requirements }(\mathrm{IR})=\mathrm{ETc}+15 \% \text { (leaching requirements). }
$$

The data of daily IR was adjusted to the volume of Polyethylene bags used and the Table 2 shows the volume of daily IR in cubic $\mathrm{cm}$ till the stage of flag leaf appearance ( 35 days old) then drought tests were carried for 21 days. After 21 days from the stress condition, the flag leaf of the main tiller of each plant was obtained during morning hours when leaves were fully turgid. The percentage of flag leaf area remaining green (\% GFLA) was measured by using the leaf area meter (Portable Living Leaf Area Meter, Model: YMJ, Zhejiang Top Instrument Co., Ltd). These assessments were carried out by the same operator in the population to avoid any bias between operator's influencing results.

The present study in the first population (Cham- $6 \times$ Variant-2) indicated that one RAPD marker (Pro primer (5 GGGTAACGCC $\left.3^{\prime}\right)$ ), four ISSR markers,(Pr8, AD5; AD2 and AD3 primers (5' (GTG)5 3'; 5' (CA)10C 3'; 5' (AGC)6G3' and 5' (ACC)6G3', respectively)) , and one SSR XGWM 382-2D (Right; CTACGTGCACCACCATTTTC and Left; GTCAGATAACGCCGTCCAAT) linked to the flag leaf senescence in wheat, were identified 
(Fig. 2). QTL for flag leaf senescence was associated with RAPD marker (Pr9 $9_{270 b p}$, ISSR markers (Pr8 380 bp., AD5 ${ }_{900 \mathrm{bp}}, \mathrm{AD} 2_{600 \mathrm{bp}}$ and AD3 ${ }_{700}$ bp.), and SSR marker (XGWM 382-2D $\mathrm{D}_{108 \mathrm{bp}}$ ) and explained $44.0 \%, 50.0 \%, 35.0 \%, 31.0 \%, 22.0 \%$ and $73 \%$ of the phenotypic variation, respectively. The genetic distance (Fig.3) between RAPD marker ( $\operatorname{Pr} 9_{270 b p}$ ) and flag leaf senescence gene was determined to be $10 \mathrm{cM}$, with LOD score of 22.9. The ISSR markers (Pr8, AD5, AD2 and AD3) have genetic distance of 10.5, 14.6, 15.6 and 18.1 cM, respectively, from flag leaf senescence gene. In addition, the genetic distance between SSR marker XGWM 382-2 $\mathrm{D}_{110 \mathrm{bp}}$ and flag leaf senescence gene was determined to be $3.9 \mathrm{cM}$, with LOD score of 33.8. Therefore, the RAPD, ISSR and SSR markers were linked to the QTL for the flag leaf senescence as indicator for drought tolerance gene in wheat. Once these markers are identified, they can be used in wheat breeding programs, as a selection tool in early generations.

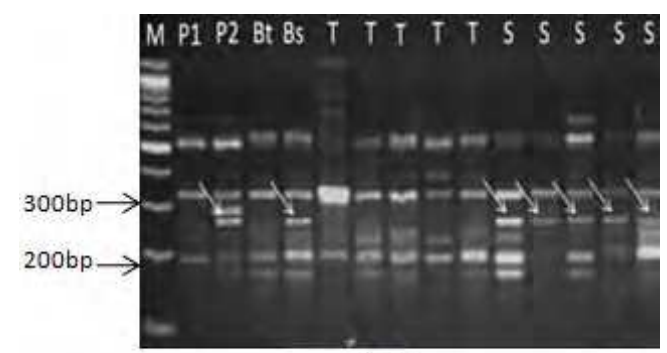

(A)

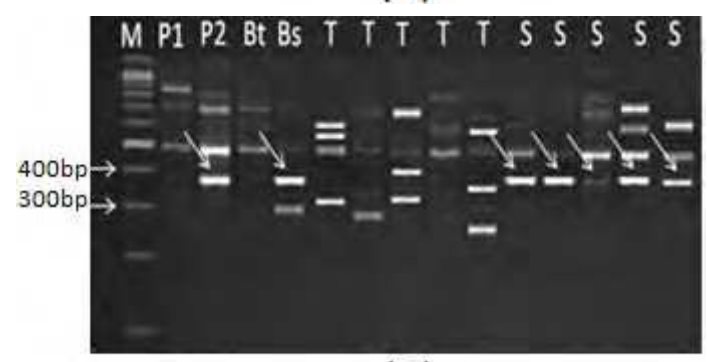

(B)

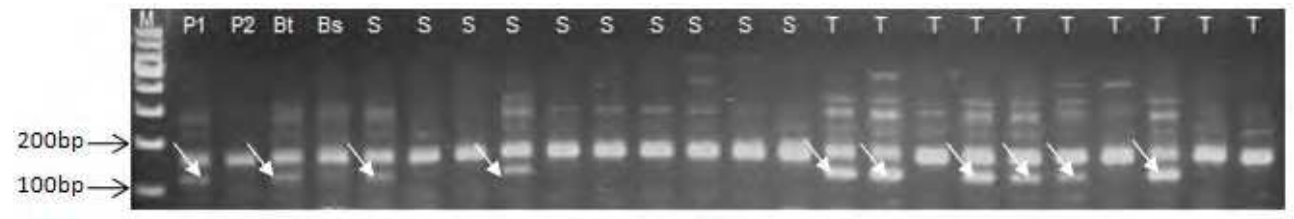

(C)

Fig. 2. RAPD fragments (A), produced by primer 9 (5 GGGTAACGCC 3'), ISSR fragments (B), produced by Pr.8 (5' (ACA CAC) 2ACA CG 3') and SSR fragments (C), produced by XGWM 382-2D. M: Molecular weight followed by $\mathrm{P}_{\mathrm{I}}$ and $\mathrm{P}_{2}$ parents Cham- 6 and Variant-2, respectively. $B_{t}$, bulk tolerant; $B s$, bulk sensitive, $F_{2}$ individuals in the cross, Cham- $6 \mathrm{X}$ Variant-2 (T: tolerant; S: sensitive) 


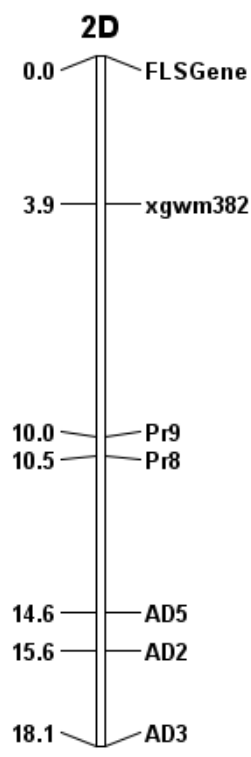

Fig. 3. RAPD marker (Pr9 270bp), ISSR markers (Pr8 $380 \mathrm{bp}$, AD5900bp; AD2 $600 \mathrm{bp}$ and AD3700bp) and SSR marker (XGWM 382-2D $110 \mathrm{bp}$ ) were located through the MAPMAKER-QTL analysis. All distances are given in centi-Morgan, using Kosambi's mapping function.

\begin{tabular}{|l|l|l|}
\hline Days & daily $\mathbf{I R} \mathbf{~ c m}^{\mathbf{3}}$ & $\begin{array}{l}\mathbf{5 0 \%} \text { of the amount of } \\
\text { daily irrigation } \mathbf{~ c m}^{\mathbf{3}}\end{array}$ \\
\hline 1-10 March & 31.9 & 15.95 \\
\hline 11-20 March & 28.2 & 14.1 \\
\hline 21-31 March & 38.9 & 19.45 \\
\hline 1-10 April & 38.1 & 19.05 \\
\hline 11-20 April & 30.3 & 15.15 \\
\hline 21-30 April & 20.9 & 10.45 \\
\hline
\end{tabular}

Table 2. Daily irrigation requirements $\left(\mathrm{cm}^{3}\right)$ from $1^{\text {st }}$ March to 30 April. Drought tests were started with the stage of flag leaf appearance.

The present study in the second population (Veery $x$ Variant-1) indicated that out of 38 RAPD arbitrary primers, screened for polymorphisms between the two tested parents (Veery and Variant-1), 24 RAPD primers (63.2\%), that gave polymorphic bands suitable to differentiate between the two parents, were identified. Of these 24 RAPD primers, $\operatorname{Pr}_{11}$ primer (5' CAATCGCCGT 3'), produced one strong polymorphic band at $230 \mathrm{bp}$, that was present only in the tolerant parent (Veery), as shown in Figure (4). The Pr11 primer was selected for screening DNA bulks and their parental DNA .The $\operatorname{Pr}_{11}$ primer, generated one polymorphic fragments at $230 \mathrm{bp}$, which was present only in tolerant bulk and Veery (tolerant parent) and were missing in sensitive bulk and Variant-1 (sensitive parent), as 
shown in Figure (4). In addition, primer Pr.19 (5`CAAACGTCGG 3'), produced a strong polymorphic band at $240 \mathrm{bp}$ that was present only in the sensitive bulked DNA, but not in the tolerant bulked DNA and primer OPU06 (5 ACCTTTGCGG 3'), produced a strong polymorphic band at $340 \mathrm{bp}$ that was present only in the sensitive bulked DNA, but not in the tolerant bulked DNA. Also, primer OPH13 (5 GACGCCACAC 3'), produced a strong polymorphic band at $450 \mathrm{bp}$ that was present only in the sensitive bulked DNA, but not in the tolerant bulked DNA. These RAPD markers (Pr11 230bp, Pr19 $240 \mathrm{bp}$, OPU06340bp and $\mathrm{OPH} 13_{450 \mathrm{bp}}$ ) were regarded as candidate markers, linked to the flag leaf senescence gene as indicator for drought tolerance.These polymorphic markers; viz, Pr11 $230 \mathrm{bp}$, Pr19 240bp $_{\text {, }}$ OPU06 $3_{40 \mathrm{bp}}$ and OPH13 ${ }_{450 \mathrm{bp}}$, were further used to check their linkage to the flag leaf senescence gene, using a segregating $\mathrm{F}_{2}$ population, derived from the cross between the tolerant parent (Veery) and the sensitive parent (Variant-1). When analyzing the individual plants of $F_{2}$ population, the Pr11 $230 \mathrm{bp}$ and OPU06 $340 \mathrm{bp}$ fragments were amplified in the DNA, obtained only in $\mathrm{F}_{2}$ tolerant ones. In addition Pr19 ${ }_{240 \mathrm{bp}}$ and OPH13 $3_{450 \mathrm{bp}}$ fragments were amplified in the DNA, obtained only in $\mathrm{F}_{2}$ sensitive ones. The RAPD markers, $\operatorname{Pr} 11_{230 \mathrm{bp}}$, Pr19 $2_{240 \mathrm{bp}}$, OPU06 $_{340 \mathrm{bp}}$ and OPH13 ${ }_{450 \mathrm{bp}} 80 ; 33 ; 67$ and 36 of 100 individuals, respectively, in the $\mathrm{F}_{2}$ population, exhibited the amplified polymorphic fragments (230, 240, 340 and 450bp), while, the remaining did not. The ratio fitted the expected Mendalian ratio, 3:1 for all markers except for OPH13 450 bp which did not fitted the ratio (Table 3).To check for potential co-segregantion of DNA fragments and drought tolerant phenotypes, correlation and simple regression analysis were carried out in order to confirm an association between the Pr11 $230 \mathrm{bp}$, Pr19 $2_{240 \mathrm{bp}}$, OPU06 ${ }_{340 \mathrm{bp}}$ and OPH13 ${ }_{450 \mathrm{bp}}$ markers and the flag leaf senescence gene as indicator for tolerant to drought in all $100 \mathrm{~F}_{2}$ progenies. The results showed that the correlation and the coefficient of determination $\left(R^{2}\right)$ for the relationship between the four markers $\left(\operatorname{Pr} 11_{230 \mathrm{bp}}\right.$, Pr19 ${ }_{240 \mathrm{bp}}$, OPU 06 $340 \mathrm{bp}$ and OPH13 $450 \mathrm{bp}$ ) and the phenotypes of $\mathrm{F}_{2}$ individuals were significant and they recorded $r=0.26,-0.71,0.49$ and -0.36 , respectively, $\mathrm{R}^{2}=0.07,0.50,0.24$ and 0.13 , respectively (Table 3). This indicates that the four markers were associated with the flag leaf senescence gene as indicator for drought tolerance.

\begin{tabular}{|c|c|c|c|c|c|c|c|c|c|c|}
\hline & \multirow{2}{*}{ Markers } & \multicolumn{3}{|c|}{ Tested of plant } & \multirow{2}{*}{$\begin{array}{c}\text { Expected } \\
\text { Ratio }\end{array}$} & \multirow{2}{*}{$\chi^{2}$} & \multirow{2}{*}{$\mathrm{r}$} & \multirow{2}{*}{$\mathrm{R}^{2}$} & \multirow{2}{*}{$\begin{array}{l}\text { QTL } \\
\text { cM }\end{array}$} & \multirow[b]{2}{*}{ LOD } \\
\hline & & Total & $\mathrm{T}$ & S & & & & & & \\
\hline \multirow{4}{*}{ 产 } & $\operatorname{Pr} 11_{230 \mathrm{bp}}$ & 100 & 80 & 20 & $3: 1$ & $1.33^{\mathrm{ns}}$ & 0.26 & $0.07 * *$ & 18.6 & 16.4 \\
\hline & $\operatorname{Pr} 19_{240 \mathrm{bp}}$ & 100 & 67 & 33 & $3: 1$ & $3.41^{\mathrm{ns}}$ & -0.71 & $0.50 * *$ & 15.0 & 19.0 \\
\hline & OPU06 $_{340 \mathrm{bp}}$ & 100 & 67 & 33 & $3: 1$ & $3.41^{\mathrm{ns}}$ & 0.49 & $0.24 * *$ & 13.2 & 20.7 \\
\hline & $\mathrm{OPH}_{13} 3_{450 \mathrm{bp}}$ & 100 & 64 & 36 & $3: 1$ & $6.4^{* *}$ & -0.36 & $0.13 * *$ & 17.4 & 16.0 \\
\hline \multirow{2}{*}{$\begin{array}{l}\mathscr{\varkappa} \\
\mathscr{\Omega}\end{array}$} & $\mathrm{M} 1_{1100 \mathrm{bp}}$ & 100 & 67 & 33 & $3: 1$ & $3.41^{\mathrm{ns}}$ & 0.50 & $0.25 * *$ & 12.5 & 21.6 \\
\hline & $\mathrm{AD} 2_{300 \mathrm{bp}}$ & 100 & 76 & 24 & $3: 1$ & $0.05^{\mathrm{ns}}$ & -0.58 & $0.34 * *$ & 10.2 & 26.0 \\
\hline
\end{tabular}

$\mathrm{T}=$ Tolerant plants, $\mathrm{S}=$ sensitive plants

$\mathrm{Ns},{ }^{* *}=$ non significant and significant at .01 level of probability

Table 3. QTL analysis and significant association between drought tolerance and markers (RAPD and ISSR) in the $100 \mathrm{~F}_{2}$ plants population of Veery $x$ Variant-1, using Chi - square $\left(X^{2}\right)$, correlation $(r)$ and coefficient of determination $\left(R^{2}\right)$ analysis. 
Out of 33 ISSR primers, screened for polymorphisms between the two tested parents, thirteen ISSR primers $(34.2 \%)$ that gave polymorphic bands suitable to differentiate between the two parents, were identified. Of these thirteen ISSR primers, M1 and AD2 primers (5'(AC) 8CG3' and 5'(AGC) 6G3', respectively), which produced two strong polymorphic bands at 1100 and $300 \mathrm{bp}$, respectively. The M1 primer produced one strong polymorphic band at $1100 \mathrm{bp}$ that was present only in the tolerant parent (Veery), as shown in Figure (5). The M1 primer was selected for screening DNA bulks and their parental DNA .The M1 primer, generated one polymorphic fragments at $1100 \mathrm{bp}$, which was present only in tolerant bulk and Veery (tolerant parent) and were missing in sensitive bulk and Variant-1 (sensitive parent), as shown in Figure (5). In addition, AD2 primer was generated one polymorphic fragment at $300 \mathrm{bp}$ that were present only in the sensitive parent (Variant-1). AD2 ISSR primer was selected for screening DNA bulks and their parental DNA. The primer AD2 generated the polymorphic fragments $300 \mathrm{bp}$, which were present only in the sensitive bulk and Variant-1 (sensitive parent) and were missing in tolerant bulk and Veery (tolerant parent). These ISSR markers ( $\mathrm{M}_{1100 \mathrm{bp}}$ and $\mathrm{AD} 2_{300 \mathrm{bp}}$ ) were regarded as candidate markers linked to the flag leaf senescence gene as indicator for drought tolerance in wheat. These polymorphic markers, $\mathrm{M}_{1100 \mathrm{bp}}$ and $\mathrm{AD} 2_{300 \mathrm{bp}}$, were further used to check their linkage to the flag leaf senescence gene, using a segregating $F_{2}$ population, derived from the cross between the tolerant parent, Veery, and the sensitive one, Variant- 1 . When analyzing the individual plants of $F_{2}$ population, the $\mathrm{M}_{1100 \mathrm{bp}}$ fragments were amplified in the DNA, obtained only in $\mathrm{F}_{2}$ tolerant ones and the $\mathrm{AD}_{300 \mathrm{bp}}$ fragments were amplified in the DNA, obtained only in $\mathrm{F}_{2}$ sensitive ones. The ISSR markers, M1 $1_{1100 \mathrm{bp}}$ and AD2 $300 \mathrm{bp}, 76$ and 24 of 100 individuals respectively, in the $\mathrm{F}_{2}$ population, exhibited the amplified polymorphic fragments (1100 and $300 \mathrm{bp}$ ), while, the remaining did not. The ratio fitted the expected Mendalian ratio, 3:1 ( $\chi^{2}=3.41$ and 0.05, $\mathrm{P}<0.1$ respectively) (Table 3).To check for potential co-segregantion of DNA fragments and drought tolerant phenotypes, correlation and simple regression analysis were carried out in order to confirm an association between the each $\mathrm{M}_{1100 \mathrm{bp}}$ and $\mathrm{AD} 2_{300 \mathrm{bp}}$ markers and the flag leaf senescence gene as indicator for the tolerance to drought in all $100 \mathrm{~F}_{2}$ progenies. The results showed that the correlation and the coefficient of determination $\left(\mathrm{R}^{2}\right)$ for the relationship between presence of the two markers, $\mathrm{M} 1_{1100 \mathrm{bp}}$ and $\mathrm{AD} 2_{300 \mathrm{bp}}$, and the phenotypes of $\mathrm{F}_{2}$ individuals were significant and they recorded $\mathrm{r}=0.5$ and -0.58 , respectively, $\mathrm{R}^{2}=0.25$ and 0.34 , respectively (Table 3 ). This indicates that the two markers were linked to the flag leaf senescence gene as indicator for drought tolerance.

The linkage relationship between the RAPD markers (Pr11 $230 \mathrm{bp}$, Pr19 ${ }_{240 \mathrm{bp}}$, OPU06 $340 \mathrm{bp}$ and $\mathrm{OPH}_{13} 3_{50 \mathrm{bp}}$ ) and the flag leaf senescence gene as indicator for drought tolerance was estimated, using $\mathrm{F}_{2}$ population, derived from the cross, Veery $\mathrm{X}$ Variant-1. The genetic distance between RAPD markers (Pr11 $230 \mathrm{bp}$, Pr19 $1_{240 \mathrm{bp}}$, OPU06 $340 \mathrm{bp}$ and OPH13 $450 \mathrm{bp}$ ) and the flag leaf senescence gene were determined to be 15.6, 15.0, 13.2 and $17.4 \mathrm{cM}$, respectively, with LOD scores of 16.4, 19.0, 20.7 and 16.0, respectively (Table 3 and Fig.6). Therefore, RAPD markers (Pr11 $230 \mathrm{bp}$, Pr19 240bp $_{1}$ OPU06 $340 \mathrm{bp}$ and OPH13 $450 \mathrm{bp}$ primers) were linked to the quantitative trait loci (QTL) for the flag leaf senescence gene as indicator for drought tolerance.

After mapmaker linkage analysis on the $\mathrm{F}_{2}$ population, the genetic distance between ISSR markers ( $\mathrm{M}_{1100 \mathrm{bp}}$ and $\left.\mathrm{AD} 2_{300 \mathrm{bp}}\right)$ and the flag leaf senescence gene was determined to be 12.5 and $10.2 \mathrm{cM}$, respectively, with LOD scores of 21.6 and 26.0, respectively (Table 3 and Fig.6). 
Therefore, ISSR markers ( $\mathrm{M}_{1100 \mathrm{bp}}$ and $\left.\mathrm{AD} 2_{300 \mathrm{bp}}\right)$ were linked to the quantitative trait loci (QTL) for the flag leaf senescence gene as indicator for drought tolerance.

One-way ANOVA was carried out using marker genotypes as groups. The ANOVA on RAPD markers (Pr11 $230 \mathrm{bp}$, Pr19 240bp, OPU06 $_{340 \mathrm{bp}}$ and OPH13 $\left.{ }_{450 \mathrm{bp}}\right)$ and ISSR markers $\left(\mathrm{M1}_{1100 \mathrm{bp}}\right.$ and $\mathrm{AD}$ 2300bp) genotypes as groups for flag leaf senescence established significant association between marker (RAPD markers and ISSR markers) and phenotype (flag leaf senescence) (Tables 3 and 4). The single marker ANOVA analysis revealed that RAPD markers-linked QTL (Pr11 $230 \mathrm{bp}$, Pr19 ${ }_{240 \mathrm{bp}}$, OPU06 $340 \mathrm{bp}$ and OPH13 $450 \mathrm{bp}$ ) accounted for 7.0\%, $50.0 \%, 24.0 \%$ and $13.0 \%$ of the total variation, respectively, in flag leaf senescence in $\mathrm{F} 2$ population. While, ISSR markers-linked QTL (M1 $1_{1100 \mathrm{bp}}$ and $\mathrm{AD} 2_{300 \mathrm{bp}}$ ) accounted for $25 \%$ and $34 \%$ of the phenotypic variation, respectively, in flag leaf senescence in F2 population, in wheat under water-stressed conditions.

\begin{tabular}{|c|c|c|c|c|c|c|}
\hline Marker & Source & DF & SS & MS & $\mathbf{F}$ & $\mathbf{P}$ \\
\hline \multirow[t]{3}{*}{$\operatorname{Pr}_{11} 230 \mathrm{bp}$} & Genotypes & 1 & 520.75 & 520.75 & 4.578 & 0.034 \\
\hline & Error & 98 & 11146.5 & 113.73 & & \\
\hline & Total & 99 & 11667.25 & & & \\
\hline \multirow[t]{3}{*}{$\operatorname{Pr}_{19} 9_{240 p}$} & Genotypes & 1 & 4057.45 & 4057.45 & 52.25 & 0.0001 \\
\hline & Error & 98 & 7609.81 & 77.65 & & \\
\hline & Total & 99 & 11667.25 & & & \\
\hline \multirow[t]{3}{*}{ OPU06 $_{340 b p}$} & Genotypes & 1 & 3029.35 & 3029.35 & 34.37 & 0.0001 \\
\hline & Error & 98 & 8637.91 & 88.14 & & \\
\hline & Total & 99 & 11667.25 & & & \\
\hline \multirow[t]{3}{*}{$\mathrm{OPH}_{13}{ }_{450 \mathrm{bp}}$} & Genotypes & 1 & 3208.85 & 3208.85 & 37.18 & 0.0001 \\
\hline & Error & 98 & 8458.41 & 86.31 & & \\
\hline & Total & 99 & 11667.25 & & & \\
\hline \multirow[t]{3}{*}{$\mathbf{M} 1_{1100 b p}$} & Genotypes & 1 & 3089.19 & 3089.19 & 35.29 & 0.0001 \\
\hline & Error & 98 & 8578.07 & 87.53 & & \\
\hline & Total & 99 & 11667.25 & & & \\
\hline \multirow[t]{3}{*}{$\mathrm{AD} 2_{300 \mathrm{bp}}$} & Genotypes & 1 & 4073.52 & 4073.52 & 52.57 & 0.0001 \\
\hline & Error & 98 & 7593.74 & 77.49 & & \\
\hline & Total & 99 & 11667.25 & & & \\
\hline
\end{tabular}

Table 4. Analysis of variance of the difference for flag leaf senescence as determinant for drought tolerance in $\mathrm{F}_{2}$ population. 


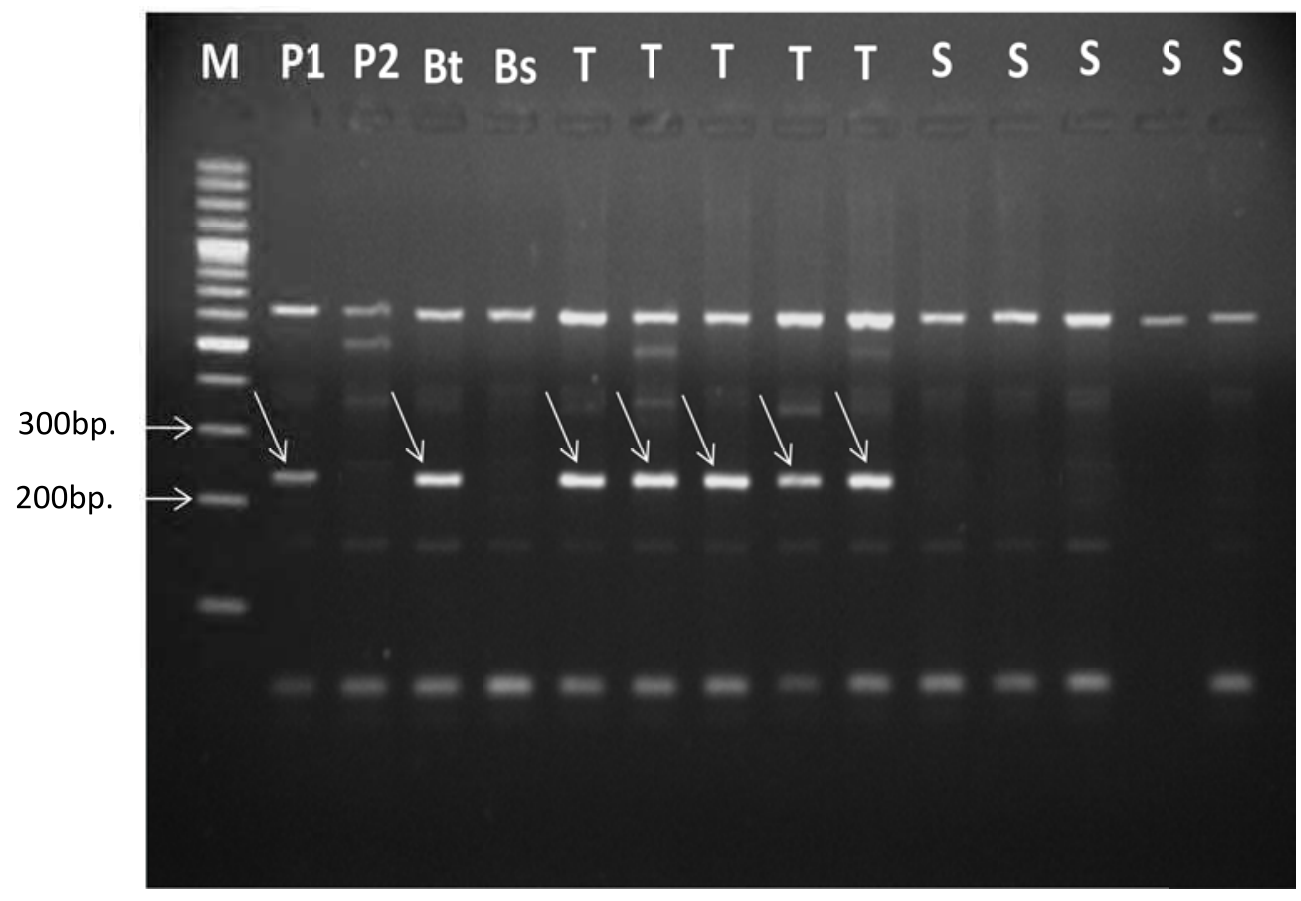

Fig. 4. RAPD fragments, produced by primer11 (5 CAATCGCCGT 3'), M: Molecular weight followed by $\mathrm{P}_{\mathrm{I}}$ and $\mathrm{P}_{2}$ parents Veery and Variant-1, respectively. Bt, bulk tolerant; Bs, bulk sensitive, $\mathrm{F}_{2}$ individuals in the cross (T: Tolerant; $\mathrm{S}$ : sensitive). Arrow points to polymorphic bands of the Pr11 $230 \mathrm{bp}$ marker. 


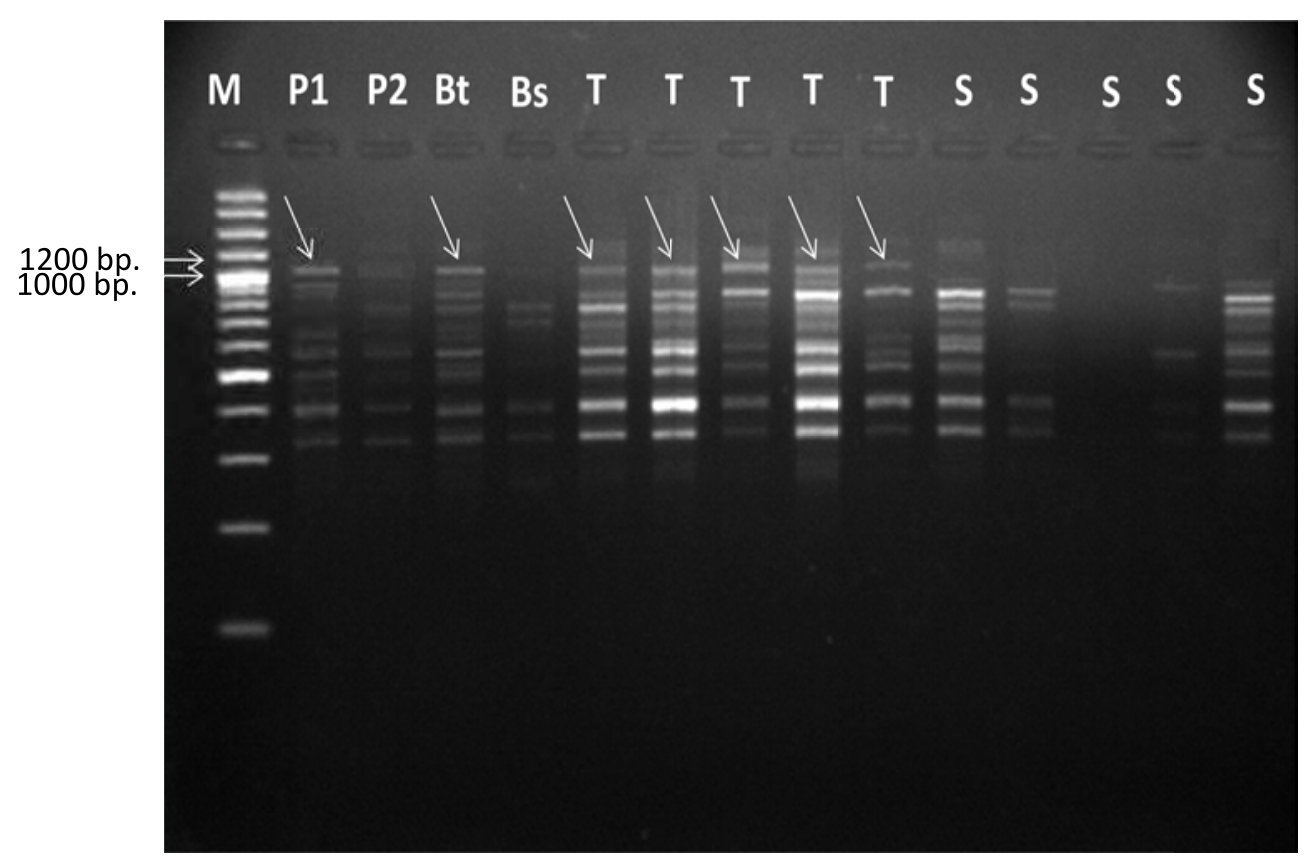

Fig. 5. ISSR fragments, produced by M1 (5` (AC)8CG 3'), M: Molecular weight, followed by $P_{I}$ and $P_{2}$ parents Veery and Variant- 1 , respectively. Bt, bulk tolerant; Bs, bulk sensitive, $F_{2}$ individuals in the cross (T: Tolerant; $\mathrm{S}$ : sensitive). Arrow points to polymorphic bands of the M11100bp marker. 


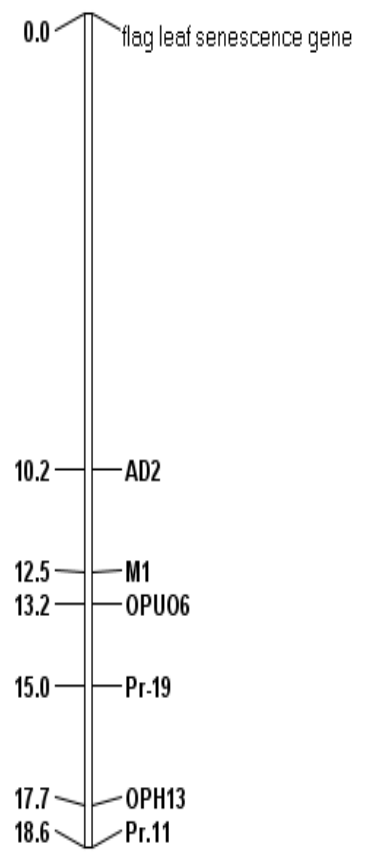

Fig. 6. RAPD markers (Pr11 230bp, Pr19240bp, OPU06 340 bp and OPH13 $450 \mathrm{bp})$, ISSR markers $\left(\mathrm{M}_{1100 \mathrm{bp}}\right.$ and $\mathrm{AD} 2_{300 \mathrm{bp}}$ ) and the flag leaf senescence gene were located through the MAPMAKER-QTL analysis. All distances are given in centi-Morgan, using Kosambi's mapping function.

Water-stress tolerance in wheat is a quantitatively inherited trait controlled by several genetic loci, and several of its genetic components are difficult to measure (Forster et al., 2000). Identification of associated molecular markers at a major locus contributing to water-stress tolerance would be useful for the indirect selection of wheat plants for waterstress tolerance (Visser, 1994). However, identifying molecular markers associated with important genes or traits in most instances requires screening of a relatively large number of individuals in the population (Lawson et al., 1994). Bulked segregant analysis (BSA) was originally developed to overcome this difficulty, because comparing bulk samples is easier than evaluating many individuals in different populations (Sweeney and Dannebeger, 1994).

The use of molecular markers can increase the efficiency of conventional plant breeding by identifying markers linked to the trait of interest, which are difficult to evaluate and/or are largely affected by the environment. Hence, there is a need to develop a rapid screening method to select for drought tolerance. Tight linkage between molecular markers and gene for flag leaf senescence can be of great benefit to drought tolerance breeding programs by allowing the investigator to follow the DNA markers (PCR-based markers) through early generation rather than waiting for phenotypic expression of the tolerance genes. Molecular 
markers that are closely linked with target alleles present a useful tool in plant breeding since they can help to detect the tolerant genes of interest without the need of carrying out field evaluation. Also, it allows for screening big number of breeding materials at early growth stages and in short time.

The present study indicated that RAPD, ISSR and SSR markers, combined with bulked segregant analysis, could be used to identify molecular markers linked to the flag leaf senescence gene as indicator for drought tolerance in wheat. Once these markers are identified, they can be used in wheat breeding programs as a selection tool in early generations.

\section{References}

Barakat, M. N., S.I. Milad \& I.A. Imbaby.2005. Field evaluation for rust diseases and RAPD analysis for somaclonal variant lines in wheat. Alex. J. Agric. Res. 50: (3) 11-24, 2005.

Beavis, W.D., O.S. Smith, D. Grant \& R. Fincher. 1994. Identification of quantitative trait loci using a small sample of top-crossed and F4 progeny from maize. Crop Sci 34: 882896.

Blum, A. 1988. Plant breeding for stress environments. CRC Press. Boca Raton, Florida, US

Chandler, J.M. 2001. Current molecular understanding of the genetically programmed process of leaf senescence. Physiologia Plantarum 113: 1-8.

Chin, E.C.L., Senior, M.L., Shu, H. and Smith,J.S.C. (1996) Maize simple repetitive DNA sequences: abundance and allele variation. Genome 39, 866-873.

Crasta, O.R., W.W. Xu, D.T. Rosenow, J. Mullet and H.T. Nguyen.1999.Mapping of postflowering drought resistance traits in grain sorghum: association between QTLs influencing premature senescence and maturity. Mol \& General Genet 262: 579-588.

Evans, L.T., 1993. Crop Evolution, Adaptation and Yield. Cambridge University Press, Cambridge, UK.

Foolad M (2005) Breeding for abiotic stress tolerances in tomato. In: Ashraf, M., Harris, P.J.C. (Eds.), Abiotic Stresses: Plant Resistance Through Breeding and Molecular Approaches. The Haworth Press Inc., New York, USA, pp. 613-684.

Forster, B.P., Ellis, R.P., Thomas, W.T.: The development and application of molecular markers for abiotic stress tolerance in barley. J. Exp. Bot. 51: 19-27, 2000

Gilles, P.N., Wu, D.J., Foster, C.B., Dillon, P.J.and Chanock, S.J. (1999) Single nucleotide polymorphic discrimination by an electronic dot blot assay on semiconductor microchips. Nature Biotechnology 17, 365-370.

Johnson, G.R. and Mumm, R.H. (1996) Marker assisted maize breeding. In: Proceedings of the 51st Annual Corn and Sorghum Research Conference, Chicago, Illinois, 11-12 December 1996. American Seed Trade Association, Washington, DC, pp. 75-84.

Harris K., P. K. Subudhi , A. Borrel , D. Jordan , D. Rosenow , H. Nguyen, P. Klein, R. Klein and J. Mullet . 2007. Sorghum stay-green QTL individually reduce post-flowering drought-induced leaf senescence. J. of Exp. Botany. 58: 327-338.

Kebede, H., P.K. Subudhi, D.T. Rosenow and H.T. Nguyen. 2001. Quantitative trait loci influencing drought tolerance in grain sorghum (Sorghum bicolor L. Moench). Theor App Genet 103:266-276. 
Lawson, W.R., Henry, R.J., Kochman, J.K., Kong, G.A.: Genetic diversity in sunflower (Helianthus annus L.) as revealed by random amplified polymorphic DNA analysis. Aust. J. Agric. Res. 45: 1319-1327, 1994.

Luo, L. J., and Q. F. Zhang. 2001.The status and strategy on drought resistance of rice (Oryza sativa L.). Chinese J. Rice Sci. 15: 209-214.

Morgante M. and F. Salamini.2003.From plant genomics to breeding practice. Curr.Opin.Biotechnol.14:214-219.

Mohan, M., Nair, S., Bhagwat, A., Krishna, T.G.,Yano, M., Bhatia, C.R. and Sasaki, T. (1997) Genome mapping, molecular markers and marker-assisted selection in crop plants. Molecular Breeding 3, 87-103.

Passioura J.B.2002. Environmental biology and crop improvement. Funct.Plant Biol.29:537-546.

Powell, W., Machray, G.C. and Provan, J. (1996) Polymorphism revealed by simple sequence repeats. Trends in Plant Science 1, 215-222.

Ribaut,j.m. et al.2002. Use of molecular markers in plant breeding drought tolerance improvement in tropical maize .In Quantitative Genetics, Genomics, and Plant Breeding(Kang,M.S.,ed),pp.85-99,CABI Publishing

Salvi S. and R.Tuberosa .2005.To clone or not to clone plant QTLs: present and future challenges. Trends Plant Sci.10:297-304.

Smith, M.: “CROPWAT: Manual and Guidelines.", FAO of UN, Rome, 1991

Sweeney, P.M., Danneberger, T.K.: Random amplified polymorphic DNA in perennial ryegrass: a comparison of bulk samples vs. individuals. Hort Science 29: 624-626, 1994.

Sylvester-Bradley, R., R.K. Scott and C.E. Wright. 1990. Physiology in the production and improvement of cereals. Home-grown Cereals Authority Research Review 18. HGCA, London.

Tripathy, J. N., J. Zhang, S. Robin and H. T. Nguyen. 2000 .QTLs for cell-membrane stability mapped in rice oryza sativa L.) under drought stress. Theor. Appl. Genet. 100: 1197-1202.

Tuberosa R. and S. Salvi, 2007.Genomics-based approaches to improve drought tolerance of crops.Trends in Plant Science 11:405-412.

Tuinstra, M.R., E.M. Grote, P.B. Goldsbrough \& G. Ejeta, 1997.Genetic analysis of postflowering drought tolerance and componentsof grain development in Sorghum bicolor (L.) Moench.Mol Breed 3: 439-448

Verma, V., Foulkes, M.J., Caligari, P., Sylvester-Bradley, R., Snape, J.: Mapping QTLs for flag leaf senescence as a yield determinant in winter wheat under optimal and droughted environments. Euphytica 135: 255-263, 2004.

Visser, B.: Technical aspects of drought tolerance. Biotechnology Dev. Monitor 18: 5, 1994.

Xu, W.W., P.K. Subudhi, O.R. Crasta, D.T. Rosenow, J.E. Mullet\& H.T. Nguyen, 2000. Molecular mapping of QTLs conferringstay-green in grain sorghum (Sorghum bicolor L. Moench).Genome 43: 461-469.

Young, ND 1999 QTL mapping and quantitative disease resistance in plants.Annu.Rev. Phytopathol.34:479-501. 


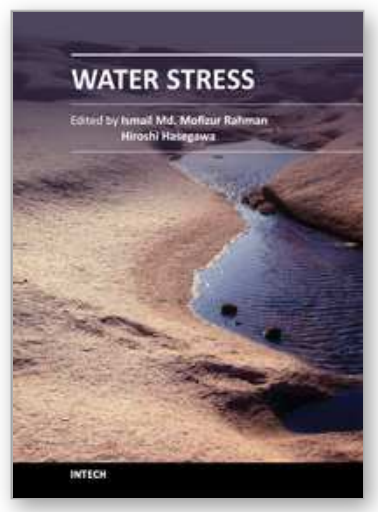

\author{
Water Stress \\ Edited by Prof. Ismail Md. Mofizur Rahman
}

ISBN 978-953-307-963-9

Hard cover, 300 pages

Publisher InTech

Published online 25, January, 2012

Published in print edition January, 2012

Plants experience water stress either when the water supply to their roots becomes limiting, or when the transpiration rate becomes intense. Water stress is primarily caused by a water deficit, such as a drought or high soil salinity. Each year, water stress on arable plants in different parts of the world disrupts agriculture and food supply with the final consequence: famine. Hence, the ability to withstand such stress is of immense economic importance. Plants try to adapt to the stress conditions with an array of biochemical and physiological interventions. This multi-authored edited compilation puts forth an all-inclusive picture on the mechanism and adaptation aspects of water stress. The prime objective of the book is to deliver a thoughtful mixture of viewpoints which will be useful to workers in all areas of plant sciences. We trust that the material covered in this book will be valuable in building strategies to counter water stress in plants.

\title{
How to reference
}

In order to correctly reference this scholarly work, feel free to copy and paste the following:

Mohamed Najeb Barakat and Abdullah Abdullaziz Al-Doss (2012). Application of Molecular Breeding for Development of the Drought-Tolerant Genotypes in Wheat, Water Stress, Prof. Ismail Md. Mofizur Rahman (Ed.), ISBN: 978-953-307-963-9, InTech, Available from: http://www.intechopen.com/books/waterstress/application-of-molecular-breeding-for-development-of-the-drought-tolerant-genotypes-in-wheat-

\section{INTECH}

open science | open minds

\author{
InTech Europe \\ University Campus STeP Ri \\ Slavka Krautzeka 83/A \\ 51000 Rijeka, Croatia \\ Phone: +385 (51) 770447 \\ Fax: +385 (51) 686166 \\ www.intechopen.com
}

\author{
InTech China \\ Unit 405, Office Block, Hotel Equatorial Shanghai \\ No.65, Yan An Road (West), Shanghai, 200040, China \\ 中国上海市延安西路65号上海国际贵都大饭店办公楼405单元 \\ Phone: +86-21-62489820 \\ Fax: $+86-21-62489821$
}


(C) 2012 The Author(s). Licensee IntechOpen. This is an open access article distributed under the terms of the Creative Commons Attribution 3.0 License, which permits unrestricted use, distribution, and reproduction in any medium, provided the original work is properly cited. 